\title{
Rola idelalizybu w leczeniu chorych na przewlekłą białaczkę limfocytową
}

\section{The role of idelalisib in the treatment of patients with chronic lymphocytic leukemia}

\author{
Bartosz Puła ${ }^{1}$, Krzysztof Jamroziak ${ }^{1}$, Ewa Lech-Marańda ${ }^{1,2}$, Krzysztof Warzocha ${ }^{1}$ \\ ${ }^{1}$ Klinika Hematologii, Instytut Hematologii i Transfuzjologii, Warszawa \\ ${ }^{2}$ Klinika Hematologii i Transfuzjologii, Centrum Medyczne Kształcenia Podyplomowego, Warszawa
}

\begin{abstract}
Streszczenie
Aktywacja receptora limfocytów B (BCR) w komórkach przewlektej biataczki limfocytowej (CLL) prowadzi do stymulacji szlaków sygnatowych warunkujacych ich przeżyie. Kinaza 3-fosfatydyloinozytolu $\delta(P I 3 K \delta)$ jest jednym $z$ kluczowych biatek uczestniczacych $w$ przekazywaniu sygnatu $z$ BCR $i$ integrujacym sygnaty $z$ receptorów chemokinowych, biatka CD40 oraz integryn. Podwyższona aktywność tej kinazy zaobserwowano w szczególności w nowotworach wywodzacych sie $z$ uktadu chtonnego, $w$ tym równiez $C L L$. W komórkach CLL PI3Kס reguluje procesy proliferacji, różicowania, apoptozy, metabolizmu, adhezji i migracji. Idelalizyb (GS-1101, CAL-101) jest obecnie jedynym zarejestrowanym i dostępnym $w$ praktyce klinicznej inhibitorem PI3Kס, który wykazat obiecujaca skuteczność w badaniach przedklinicznych i klinicznych. W niniejszej publikacji omówiono mechanizmy działania, skuteczność kliniczna oraz profil dziatań niepożąanych leczenia idelalizybem.
\end{abstract}

Słowa kluczowe: przewlekła białaczka limfocytowa, receptor limfocytów B, kinaza 3-fosfatydyloinozytolu delta

Hematologia 2016; 7, 3: 217-230

\begin{abstract}
$B$-cell receptor (BCR) activation in chronic lymphocytic leukemia (CLL) cells leads to stimulation of signaling pathways warranting their survival. The phosphoinositide 3-kinase delta (PI3KX) is one of the key proteins participating in the propagation of the BCR signal and integrating signals from chemokine receptors, CD40 protein and integrins. Increased activity of this kinase was particularly observed in lymphoid derived tumors, including CLL. Idelalisib (GS-1101, CAL-101) is currently the only approved and available in clinical practice PI3KD inhibitor, which showed promising activity in the preclinical studies and clinical trials. In this publication we discuss the mechanism of action, clinical activity and adverse event profile of idelalisib treatment.
\end{abstract}

Key words: chronic lymphocytic leukemia, B-cell receptor, phosphoinositide 3-kinase delta

Hematologia 2016; 7, 3: 217-230

Adres do korespondencji: Bartosz Puła, Klinika Hematologii, Instytut Hematologii i Transfuzjologii, ul. Indiry Gandhi 14, 02-776 Warszawa, tel. 223496 302, faks 223496 335, e-mail: bartosz.pula@gmail.com 


\section{Wprowadzenie}

Przewlekła białaczka limfocytowa (CLL, chronic lymphocytic leukemia) jest najczęściej diagnozowaną białaczką w populacji osób dorosłych w krajach zachodnich. Rocznie w Stanach Zjednoczonych diagnozowanych jest około 18000 nowych zachorowań według danych rejestru SEER (Surveillance, Epidemiology and End Results). W Polsce natomiast według szacunków Polskiego Towarzystwa Hematologów i Transfuzjologów rocznie stwierdza się około 1500 nowych zachorowań. Komórki CLL to zróżnicowane komórki wywodzące się z limfocytów B i charakteryzujące się ekspresją antygenów CD5, CD19, CD23 oraz słabą ekspresją antygenu CD20 [1]. Przebieg kliniczny CLL jest bardzo zróżnicowany, przy czym część pacjentów nie ma objawów klinicznych i nigdy nie wymaga leczenia, podczas gdy u innych od początku choroby obserwuje się dynamicznie postępującą limfocytozę i organomegalię lub izolowane cytopenie autoimmunizacyjne [2]. Aktualnie stosowane skale zaawansowania choroby według Bineta oraz Raia pozwalają przewidzieć przebieg kliniczny CLL, który $\mathrm{w}$ większości przypadków ma indolentny charakter. W przypadku obecności takich cech kliniczno-patologicznych, jak niezmutowany status genów segmentu $\mathrm{V}$ zmiennego łańcucha ciężkiego immunoglobulin ( $\mathrm{IgVH}$, immunoglobulin variable heavy chain), obecności delecji 17p13 (locus genu TP53), delecji 11q22-23 (locus genu ATM) czy mutacji genów TP53 oraz NOTCH1, rokowanie jest niekorzystne $[1,3]$. Choroba $z$ reguły dobrze reaguje na immunochemioterapię I linii leczenia, jednak wraz $z$ kolejnymi liniami leczenia dochodzi do selekcji klonów opornych $z$ towarzyszącą kumulacją zmian genetycznych, które prowadzą ostatecznie do wzrostu chemiooporności oraz progresji choroby [4-6].

Badania przeprowadzone $\mathrm{w}$ ostatnich latach pozwoliły na lepsze poznanie biologii CLL, co umożliwiło zdefiniowanie nowych potencjalnie specyficznych celów terapeutycznych [5]. Dotychczas powszechnie stosowaną i uznaną formą leczenia CLL były schematy łączące klasyczne związki cytostatyczne (tj. fludarabina, kladrybina, cyklofosfamid, chlorambucyl, bendamustyna) $z$ przeciwciałem monoklonalnym anty-CD20 (rytuksymab) [1]. Badania eksperymentalne pozwoliły na opracowanie nowych skutecznych leków działających na szlaki sygnałowe związane $z$ receptorem limfocytów $B$ (BCR, B-cell receptor), indukcją apoptozy (antagoniści białka BCL-2) czy związków działających na poziomie epigenetycznym, czyli inhibitorów deacetylazy histonowej (HDAC, histone deacetylase inhibitors) [3, 7].

Aktywacja BCR w prawidłowych limfocytach B prowadzi do ich różnicowania, przeżycia oraz produkcji przeciwcial [8]. Natomiast w przypadku komórek CLL wykazano dwa różne sposoby regulacji aktywności tego receptora. Pierwsza droga, zależna od liganda, jest indukowana po połączeniu się BCR z cząsteczką sygnałową (antygen, cząsteczka IgM), co prowadzi do jego aktywacji. Drugi sposób, tak zwana stała aktywność toniczna zależna od kinaz tyrozynowych Lyn oraz Syk, warunkuje przeżycie komórek CLL [9]. Aktywacja BCR skutkuje stymulacją 3 szlaków sygnałowych: fosfolipazy C- $\gamma 2$ (PLC- $\gamma 2$, phosholipase C- $\gamma 2$ ), kinazy Brutona (BTK, Bruton's tyrosine kinase) oraz kinazy 3-fosfatydyloinosytolu (PI3K, phosphoinositide 3-kinase) [8].

\section{Znaczenie szlaku PI3K w limfocytach B oraz komórkach CLL}

Grupa kinaz PI3K stanowi heterogenną grupę enzymów podzielonych na 3 różne klasy. Najważniejsza $z$ punktu widzenia rozwoju limfocytów $B$ oraz CLL jest klasa I, która odpowiada w komórkach za fosforylację fosfatydyloinozytolo-(4,5)-bisfosforanu (PIP2) do fosfatydyloinozytolo-(3,4,5)-trifosforanu (PIP3) stanowiącego wtórny przekaźnik sygnału BCR [10]. Wśród PI3K klasy I wyróżnia się izoformy $\mathrm{PI} 3 \mathrm{~K} \alpha, \mathrm{PI} 3 \mathrm{~K} \beta$ oraz $\mathrm{PI} 3 \mathrm{~K} \delta$ będące heterdimerami zbudowanymi $z$ podjednostki regulatorowej zbiorczo określanej jako p85 (p85 $\alpha, \mathrm{p} 55 \alpha, \mathrm{p} 50 \alpha, \mathrm{p} 85 \beta$, $\mathrm{p} 55 \gamma)$ oraz katalitycznej (p110 $\alpha, \mathrm{p} 110 \beta, \mathrm{p} 110 \delta)$. Izoforma PI3K $\gamma$ jest również heterdimerem składającym się $z$ połączenia podjednostki p101 lub p84 $z$ podjednostką p110 [11]. Izoformy $\alpha$ oraz $\beta$ występują w większości typów komórek, natomiast izoforma $\gamma$ bierze udział w rozwoju limfocytów T [12]. Ekspresja PI3K $\delta$ ograniczona jest głównie do komórek układu hematopoetycznego, w których stwierdza się bardzo wysoką ekspresję tej kinazy. $\mathrm{W}$ prawidłowych limfocytach B wykazano również niski poziom ekspresji izoform $\alpha$ oraz $\gamma$ przy praktycznie niewykrywalnym stężeniu izoformy $\beta$ [13]. $\mathrm{W}$ dotychczasowych badaniach wskazano, że PI3K $\delta$ wspólnie $z$ PI3K $\alpha$ warunkuje prawidłowy rozwój limfocytów B, a myszy pozbawione ekspresji PI3K $\delta$ charakteryzuje: brak limfocytów B1, obniżona liczba limfocytów B z towarzyszącym upośledzeniem zdolności syntezy przeciwciał i odporności oraz rozwój choroby zapalnej jelit $[13,14]$. Komórki B wyizolowane $z$ krwi myszy pozbawionych ekspresji tej izoformy charakteryzuje ponadto niska fosforylacja kinazy białkowej B (AKT, PKB [protein kinase B]) 
$[14,15]$. Natomiast zahamowanie ekspresji PI3K $\gamma$ prowadzi do upośledzenia rozwoju limfocytów $\mathrm{T}$ przy prawidłowej funkcji limfocytów B [16].

Kinaza PI3K $\delta$ jest jednym $z$ kluczowych białek odpowiadających za przekazywanie sygnału z BCR. Poprzez regulacje stężenia PIP3 i aktywności AKT PI3K $\delta$ bierze udział w kontroli takich procesów, jak: proliferacja, różnicowanie, apoptoza, metabolizm oraz adhezja i migracja [17]. Aktywność tej kinazy może być również stymulowana w wyniku aktywacji innych niż BCR receptorów i białek błonowych, czyli receptorów chemokinowych CXCR4 (chemokine CXC motif receptor 4) i CXCR5 (chemokine CXC motif receptor 5), białka CD40 oraz integryn $[18,19]$. Antagonistyczne działanie w stosunku do aktywności PI3K w limfocytach B wykazują fosfatazy lipidowe PTEN (phosphatase and tensin homolog) oraz SHIP (SH2-containing inositol phosphatase 1), które defosforylują PIP3 do PIP1, prowadząc w ten sposób do spadku aktywności AKT [20].

Eksperymentalnie wykazano onkogenną rolę $\mathrm{PI} 3 \mathrm{~K} \delta$, indukując jej nadekspresję $\mathrm{w}$ fibroblastach embrionalnych kurcząt (CEF, chicken embryo fibroblasts), co prowadziło do ich transformacji nowotworowej [21]. Ponadto podwyższoną aktywność tej kinazy zaobserwowano w szczególności w komórkach nowotworów wywodzących się $z$ układu chłonnego - w chłoniaku grudkowym (FL, follicular lymphoma), chłoniaku Hodgkina (HL, Hodgkin lymphoma), chłoniaku rozlanym $z$ dużych komórek B (DLBCL, diffuse large B-cell lymphoma), chłoniaku $\mathrm{z}$ komórek płaszcza (MCL, mantle cell lymphoma) oraz CLL [22-26].

\section{Rola PI3K w komórkach CLL}

Biorąc pod uwagę proonkogenny charakter PI3K $\delta$ oraz ograniczenie ekspresji tej kinazy głównie do komórek układu hematopoetycznego, zahamowanie aktywności PI3K $\delta$ może stanowić obiecującą i skuteczną metodę leczenia wymienionych nowotworów wywodzących się $z$ układu chłonnego. Obecnie jedynym zarejestrowanym do użytku klinicznego inhibitorem PI3K $\delta$ jest idelalizyb (GS-1101, CAL-101; preparat Zydelig ${ }^{\circledR}$, firmy Gilead). Ten drobnocząsteczkowy związek w wysoce specyficzny i odwracalny sposób blokuje PI3K $\delta$. $\mathrm{W}$ badaniach przedklinicznych wykazano istotnie wyższy poziom aktywności PI3K $\delta$ w komórkach CLL $\mathrm{w}$ porównaniu $z$ prawidłowymi limfocytami B [25]. Zahamowanie jej aktywności $z$ użyciem idelalizybu prowadziło do śmierci komórek CLL przez indukcję apoptozy zależnej od kaspaz. Warto nadmienić, że efekt ten był niezależny od występowania niekorzystnych czynników rokowniczych
CLL — obecności delecji 17p13 oraz delecji 11q22 $[25,26]$. W komórkach CLL poddanych działaniu idelalizybu stwierdzano obniżoną aktywność AKT oraz kompleksu kinazy aktywowanej mitogenem (MAPK, mitogen-activated protein kinase) $[18,26]$.

Cytotoksyczność idelalizybu w stosunku do prawidłowych limfocytów B była znacząco niższa $\mathrm{w}$ porównaniu $\mathrm{z}$ komórkami CLL, natomiast w przypadku limfocytów T oraz komórek naturalnej cytotoksyczności (NK, natural killers) lek nie wykazywał istotnego działania cytotoksycznego [25]. Po zastosowaniu idelalizybu obserwowano obniżone stężenie cytokin wytwarzanych przez komórki T oraz NK, odpowiedzialne za stymulację proliferacji komórek CLL, czyli interleukiny 6 (IL-6), IL-10, czynnika martwicy nowotworów $\alpha$ (TNF $\alpha$, tumor necrosis factor $\alpha$ ) oraz interferonu $\gamma$ (IFN $\gamma$, interferon $\gamma$ ) [25]. Jednak idelalizyb nie upośledzał cytotoksyczności zależnej od dopełniacza (ADCC, antigen-dependent complement cytotoxicity) komórek NK, jednego $z$ mechanizmów działania rytuksymabu, obinotuzumabu oraz alemtuzumabu [25, 27].

Ponadto idelalizyb blokuje również stymulujące oddziaływanie mikrośrodowiska na komórki CLL przez ograniczenie syntezy czynnika aktywującego limfocyty B (BAFF, B-cell activating factor), TNF $\alpha$ oraz cytokin: CCL3, CCL4 i CXCL13 [18, 25]. Idelalizyb blokuje również adhezję komórek CLL do komórek mikrośrodowiska oraz komórek śródbłonka w wyniku hamowania szlaku sygnałowego receptorów CXCR4 oraz CXCR5, stymulowanych przez wymienione cytokiny. Prowadzi to do ich migracji $z$ węzłów chłonnych oraz szpiku kostnego do krwi obwodowej, gdzie pozbawione ochronnego działania komórek mikrośrodowiska ulegają apoptozie [19, 28, 29]. Mechanizm ten zdają się potwierdzać obserwacje kliniczne u pacjentów leczonych idelalizybem, u których głównie w pierwszych tygodniach leczenia dochodzi do przejściowego wzrostu limfocytozy [30].

\section{Skuteczność kliniczna idelalizybu w badaniach I fazy}

Plejotropowe działanie idelalizybu na komórki CLL oraz obiecujące wyniki badań przedklinicznych zaowocowały badaniami wczesnej fazy na zdrowych ochotnikach oraz chorych $z$ opornymi i nawrotowymi nowotworami układu chłonnego (tab. 1). W badaniu pierwszej fazy określono bezpieczne dawki leku (400 mg jako jednokrotną największą dawkę oraz $200 \mathrm{mg} 2 \times /$ d. przez 7 dni jako największą wielokrotną dawkę), nie obserwując znaczących skutków niepożądanych nawet przy największych dawkach leku [31]. 


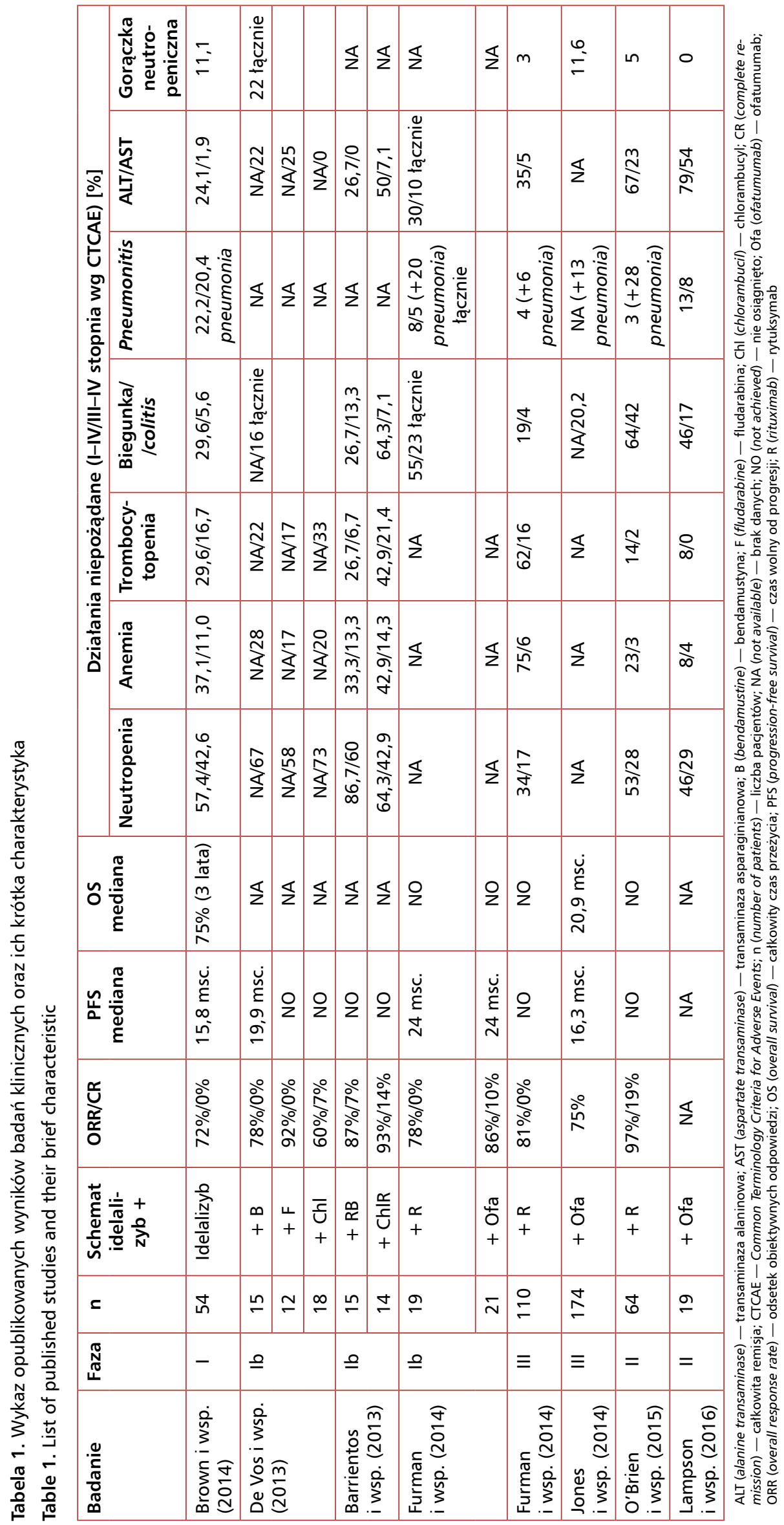


Kontynuacją tej próby było badanie kliniczne I fazy (\#NCT00710528), prowadzone przez Brown i wsp. [30], w którym skuteczność idelalizybu badano u 54 pacjentów $z$ oporną i nawrotową postacią CLL po medianie pięciu linii leczenia (zakres 2-14 linii). Badana grupa charakteryzowała się częstym występowaniem niekorzystnych czynników rokowniczych, w tym obecnością masywnej limfadenopatii (80\% chorych), oporności na leczenie poprzedniej linii $(70 \%)$, niezmutowanego statusu genu $\operatorname{IgVH}(91 \%)$, delecji $17 \mathrm{p} 13$ lub mutacji genu TP53 (24\%), delecji 11q22 (28\%) oraz mutacji genu NOTCH1 (17\%). Pacjenci otrzymywali idelalizyb w monoterapii w dawkach od 50-350 mg raz lub 2 razy/dobę [30]. Niezależnie od przyjmowanej dawki leku idelalizyb w badanej grupie pacjentów charakteryzował się wysoką skutecznością kliniczną. U 81,5\% pacjentów obserwowano redukcję mas węzłowych, natomiast zmniejszenie rozmiarów śledziony i wątroby wykazano odpowiednio u $100 \%$ i $78 \%$ pacjentów. Leczenie skutkowało również poprawą w odniesieniu do stężenia hemoglobiny $(68 \%)$, płytek krwi $(79 \%)$ oraz granulocytów $(100 \%)$. W badaniu osiągnięto wysoki odsetek obiektywnych odpowiedzi (ORR, overall response rate) sięgający $72 \%$, jednak żaden $z$ pacjentów nie uzyskał całkowitej remisji (CR, complete remission). Na uwagę zasługuje fakt, że również chorzy $z$ niekorzystnymi czynnikami rokowniczymi (obecność delecji 17p13 lub mutacji TP53) osiągali korzyść $z$ leczenia idelalizybem (ORR 54\%). Mediana czasu do osiągnięcia odpowiedzi wyniosła miesiąc, natomiast mediana czasu trwania odpowiedzi (DOR, duration of response) 16,2 miesiąca. Czas wolny od progresji (PFS, progression-free survival) dla całej badanej grupy był równy 15,8 miesiąca, mediana całkowitego przeżycia (OS, overall survival) nie została osiągnięta, natomiast odsetek pacjentów żyjących po 36 miesiącach od rozpoczęcia leczenia wynosił 75\%. Analiza grup pacjentów w zależności od przyjmowanej dawki leku wykazała, że osoby otrzymujące $150 \mathrm{mg}$ idelalizybu 2 razy/dobę $(\mathrm{n}=$ $=28$ ) charakteryzowały się istotnie dłuższym PFS (mediana 32 miesiące) w porównaniu $z$ tymi, które otrzymywały mniejsze dawki leku $(n=26$, mediana 7 miesięcy). Na podstawie tych obserwacji ustalono rekomendowaną dawkę idelalizybu wynoszącą $150 \mathrm{mg} 2 \mathrm{razy} / \mathrm{dobę} \mathrm{[30].}$

Leczenie idelalizybem $\mathrm{w}$ monoterapii chorych $z$ CLL prowadziło do przejściowego wzrostu limfocytozy spowodowanego uwalnianiem komórek nowotworu $z$ narządów układu chłonnego do krwiobiegu, gdzie pozbawione są ochronnego wpływu komórek mikrośrodowiska. Zjawisko to występowało nawet do 24 tygodnia od momentu rozpoczęcia leczenia i nie wiązało się $z$ progresją choroby [25, 26, 30]. W badaniu Brown i wsp. [30] utrzymującą się wysoką leukocytozę przy równoczesnym spełnieniu innych kryteriów częściowej remisji choroby stwierdzono u $33 \%$ chorych (odpowiedź ta określana jest obecnie jako PR-L [partial remission with lymphocytosis]).

Ze względu na dobre wyniki monoterapii idelalizybem, w szczególności w grupie pacjentów $z$ obecnością defektów szlaku TP53, oraz wyniki badań przedklinicznych przeprowadzono badanie fazy Ib oceniające terapię skojarzoną w grupie 114 pacjentów $z$ nawrotową i oporną postacią CLL [32]. Celem tego badania była ocena skuteczności i tolerancji leczenia idelalizybem $\mathrm{w}$ połączeniu $\mathrm{z}$ lekami cytostatycznymi: fludarabiną $(\mathrm{F})$, bendamustyną (B) i chlorambucylem (Chl), przeciwciałami monoklonalnymi anty-CD20 - rytuksymabem (R) oraz ofatumumabem (Ofa), jak również w kombinacji $z$ chemioimmunoterapią BR oraz ChlR. Mediana wcześniej otrzymanych linii leczenia w badanej grupie wynosiła 3 (zakres 1-9); pacjenci charakteryzowali się również częstym występowaniem niekorzystnych czynników rokowniczych: niezmutowanego statusu genu $\operatorname{IgVH}(79 \%)$, del 17p13 lub mutacji genu TP53 (29\%), del 11q22 (13\%) oraz mutacji genu NOTCH1 (28\%) [32, 33].

W kombinacji $z$ tradycyjnymi cytostatykami idelalizyb stosowano w stałej dawce $150 \mathrm{mg} 2 \mathrm{razy} /$ /dobę (w przypadku 4 pacjentów $100 \mathrm{mg} 2 \times / \mathrm{d}$.), natomiast pozostałe leki podawano w odpowiednich cyklach co 28 dni. Fludarabinę stosowano w dawce $40 \mathrm{mg} / \mathrm{m}^{2} \mathrm{w}$ dniach $1 .-5$. przez 6 cykli $(\mathrm{n}=12)$, $\mathrm{B}$ w dawce $90 \mathrm{mg} / \mathrm{m}^{2} \mathrm{w}$ dniach 1.-2. przez 6 cykli ( $\mathrm{n}=15), \mathrm{Chl} \mathrm{w}$ dawce $10 \mathrm{mg} / \mathrm{m}^{2} \mathrm{w}$ dniach 1.-7. przez 3-12 cykli $(n=18)$ [34]. Kombinacja idelalizybu $z$ analizowanymi klasycznymi cytostatykami wykazała obiecującą skuteczność kliniczną przy akceptowalnym profilu działań niepożądanych. $\mathrm{W}$ całej badanej grupie 45 pacjentów ORR wynosił $78 \%$, natomiast w przypadku poszczególnych ramion badania osiągnięto odpowiednio: $92 \%$ PR i 0\% CR dla skojarzenia $z$ F, 78\% PR i 0\% CR dla skojarzenia $z$ B oraz $60 \%$ PR i $7 \%$ CR dla skojarzenia $z$ Chl. Również w przypadku chorych charakteryzujących się występowaniem del 17p13 lub mutacji TP53 obserwowano dobrą odpowiedź kliniczną z ORR wynoszącym $70 \%$ w porównaniu z 83\% u pacjentów, u których nie stwierdzono tych niekorzystnych czynników rokowniczych. Mediana czasu do uzyskania odpowiedzi wynosiła 1,9 miesiąca, DOR 26,6 miesiąca, natomiast PFS 28,5 miesiąca [34]. 
Skuteczność kliniczną idelalizybu analizowano również $\mathrm{w}$ kombinacji $\mathrm{z}$ monoklonalnymi przeciwciałami anty-CD20 (R oraz Ofa) [35]. W tej części badania udział wzięło 40 pacjentów $z$ nawrotową oraz oporną postacią CLL po wielu liniach leczenia. W badanej grupie $98 \%$ pacjentów było już wcześniej leczonych $\mathrm{R}$, natomiast w 55\% przypadkach wykazano oporność na ten lek. W badaniu idelalizyb stosowano w dawce $150 \mathrm{mg} 2 \mathrm{razy} /$ dobę (u 4 pacjentów $100 \mathrm{mg}$ /dobę w grupie leczonej rytuksymabem). Rytuksymab podawano w dawce $375 \mathrm{mg} / \mathrm{m}^{2}$ w odstępach cotygodniowych, podając łącznie 8 kursów (19 pacjentów), natomiast Ofa podawano łącznie w 12 infuzjach (dawka początkowa $300 \mathrm{mg}$, następnie 7 kursów po 1000 mg cotygodniowo i kolejne 4 kursy w dawce $1000 \mathrm{mg}$ co 4 tygodnie). W badaniu wykazano ORR na poziomie $83 \%$, w tym 2 pacjentów osiągnęło CR (5\%). Mediana czasu do uzyskania odpowiedzi wynosiła 1,9 miesiąca, natomiast mediany DOR oraz PFS wynosiły 24 miesiące. Wśród 11 pacjentów wykazano obecność delecji 17p13 lub mutacji TP53, jednak skuteczność leczenia w tej grupie (ORR 70\%, mediana DOR 24 miesiące, mediana PFS 20 miesięcy) nie różniła się znacząco $\mathrm{w}$ porównaniu $\mathrm{z}$ obserwowaną $\mathrm{u}$ pozostałych chorych. Leczenie charakteryzowało się dość dobrą tolerancją oraz akceptowalnym profilem toksyczności [36].

Opisane badanie kliniczne fazy Ib z udziałem siedmiu grup pacjentów podsumowali Barrientos i wsp. [32]. W analizowanej grupie 114 pacjentów mediana czasu leczenia wynosiła 14,6 miesiąca (zakres 0-49 miesięcy). Łącznie w badaniu ORR wyniósł $82,5 \%$ dla wszystkich pacjentów, natomiast w podgrupie $z$ obecnością defektów szlaku TP53 osiągnął $70 \% \mathrm{w}$ porównaniu $z \quad 87 \%$ u pozostałych chorych. Mediana PFS wynosiła 26,1 miesiąca $\mathrm{w}$ całej badanej grupie, odpowiednio: dla pacjentów $z$ delecją 17 p lub mutacją TP53 - 20,3 miesiąca, natomiast $\mathrm{u}$ pacjentów bez tych zmian $-36,8$ miesiąca [32]. Wśród pacjentów, którzy uzyskali korzystną odpowiedź, 61 osób (54\%) kontynuuje przyjmowanie idelalizybu w ramach kolejnego badania klinicznego (\#NCT01090414). Wyniki tego badania nie są jednak jeszcze znane.

Mimo obiecujących rezultatów działania idelalizybu w monoterapii oraz $\mathrm{w}$ przedstawionych wcześniej kombinacjach odsetek całkowitych odpowiedzi pozostawał na niskim poziomie. $\mathrm{W}$ celu wzmocnienia efektu inhibitora PI3K $\delta$ lek stosowano w kombinacji $z$ immunochemioterapią opartą na schematach $\mathrm{RB}$ oraz RChl $[35,37]$. Do badania włączono 29 pacjentów z CLL po wielu liniach leczenia (mediana 3), wśród których 55\% charak- teryzowało się opornością na R. Pacjenci w grupie RB-idelalizyb ( $\mathrm{n}=15,28$-dniowy cykl) otrzymywali idelalizyb w dawce $150 \mathrm{mg} 2 \mathrm{razy} /$ dobę, Rw 1. dniu cykli 1.-6. w dawce $375 \mathrm{mg} / \mathrm{m}^{2}$, B w dniach 1. i 2. cykli 1.-6. w dawce $70 \mathrm{lub} 90 \mathrm{mg} / \mathrm{m}^{2}$. W grupie RChl-idelalizyb $(n=14)$ dawkowanie idelalizybu oraz rytuksymabu było podobne jak w schemacie $\mathrm{RB}$-idelalizyb, natomiast $\mathrm{Chl}$ podawano $\mathrm{w}$ dniach 1.-7. cykli 1.-12. w dawce $10 \mathrm{mg} / \mathrm{m}^{2}$. Analiza badania wykazała łączny ORR na poziomie 89,7\% przy akceptowalnym profilu działań niepożądanych [35]. Mediana czasu do uzyskania odpowiedzi wyniosła 1,9 miesiąca. W grupie leczonej według schematu RB-idelalizyb ORR wyniósł 86,7\% (80\% PR oraz $6,7 \% \mathrm{CR}$ ) oraz nie osiągnięto mediany DOR i PFS przy medianie czasu obserwacji wynoszącej 18,6 miesiąca. Natomiast w grupie pacjentów leczonych według schematu RChl-idelalizyb ORR był równy 92,9\% (78,6\% PR oraz $14,3 \% \mathrm{CR})$, nie osiągnięto mediany DOR i PFS przy medianie czasu obserwacji wynoszącej 7,7 miesiąca [35].

\section{Skuteczność idelalizybu w badaniach II i III fazy}

Wysoka skuteczność oraz akceptowalny profil działań niepożądanych idelalizybu obserwowane w badaniach klinicznych I fazy były podstawą do przeprowadzenia badań II i III fazy. W wieloośrodkowym dwuramiennym badaniu III fazy (Study 116; \#NCT01539512) oceniono skuteczność kombinacji idelalizybu $\mathrm{z}$ rytuksymabem (R-idelalizyb, $\mathrm{n}=110$ ) $\mathrm{W}$ porównaniu $\mathrm{z}$ R-placebo $(\mathrm{n}=110) \mathrm{w}$ grupie 220 chorych $z$ nawrotową i oporną CLL [38]. W badaniu uczestniczyli pacjenci, u których nawrót choroby wystąpił w ciągu 24 miesięcy od zakończenia leczenia poprzedniej linii lub mielosupresja uniemożliwiała podjęcie kolejnej linii leczenia za pomocą leków cytotoksycznych. Warto nadmienić, że do badania kwalifikowano wyłącznie osoby $z$ przewlekłą chorobą nerek (klirens kreatyniny $<60 \mathrm{ml} / \mathrm{min}$ ) lub z licznymi obciążeniami (punktacja w Cumulative Illness Rating Scale > 6) uniemożliwiającymi podanie klasycznej chemioterapii. W przypadku 95 pacjentów stwierdzano delecję 17 p13 lub mutację genu TP53, natomiast 184 chorych charakteryzowało się niezmutowanym statusem $\operatorname{IgVH}$, przy czym odsetek osób z niekorzystnymi cechami w obu badanych ramionach był porównywalny. Warunkiem kwalifikacji do badania było wcześniejsze leczenie schematem zawierającym $\mathrm{R}$ lub przynajmniej dwoma liniami leczenia w przypadku niestosowania tego przeciwciała monoklonalnego [38]. W przypadku progresji 
choroby pacjenci otrzymujący R-placebo mogli wziąć udział w badaniu przedłużającym (Study 117; \#NCT01539291) i otrzymać leczenie według schematu R-idelalizyb. W przypadku grupy leczonej schematem R-idelalizyb chorzy otrzymywali $\mathrm{w}$ badaniu przedłużającym idelalizyb w monoterapii w dawce $300 \mathrm{mg} 2$ razy/dobę [38].

W badaniu 116 idelalizyb podawano w standardowej dawce $150 \mathrm{mg} 2 \mathrm{razy} /$ dobę, natomiast $\mathrm{R}$ podawano 8-krotnie w początkowej dawce $375 \mathrm{mg} /$ $/ \mathrm{m}^{2} \mathrm{w}$ dniu rozpoczęcia leczenia, a następnie w dawce $500 \mathrm{mg} / \mathrm{m}^{2} \mathrm{w}$ odstępach 2-tygodniowych przez kolejne 4 podania, po których odstęp zwiększano do 4 tygodni (podania 6-8 leku). Dodatkowe 2 dawki rytuksymabu w pierwszych 2 miesiącach leczenia miały na celu zwiększenie efektu cytotoksycznego wobec komórek CLL uwolnionych $z$ narządów limfatycznych do krwi obwodowej [18]. Badanie przerwano przedwcześnie ze względu na znaczną przewagę schematu R-idelalizyb. Mediana PFS w grupie leczonej R-placebo wynosiła 5,5 miesiąca, natomiast w przypadku grupy leczonej inhibitorem $\mathrm{PI} 3 \mathrm{~K} \delta$ nie została osiągnięta. Odnotowano również znaczną różnicę na korzyść schematu R-idelalizyb w przypadku ORR (81\% v. 13\%), redukcji limfadenopatii $(93 \% v .4 \%)$, odsetka przeżyć w 12 . miesiącu po rozpoczęciu leczenia $(92 \%$ v. $80 \%)$. Korzystny efekt idelalizybu obserwowano również u pacjentów $z$ występowaniem niekorzystnych rokowniczo cech (np. defektu szlaku TP53 lub niezmutowanego $\operatorname{IgVH}$ ) zgodnie $\mathrm{z}$ wynikami badań klinicznych fazy I [34, 36, 37]. Badanie 116 stało się podstawą do rejestracji idelalizybu do leczenia pacjentów $z$ nawrotową lub oporną postacią CLL w Stanach Zjednoczonych, a następnie w Europie, odpowiednio: w lipcu i październiku 2014 roku.

Idelalizyb badano równie $\dot{z} \mathrm{w}$ połączeniu $\mathrm{z}$ innym przeciwciałem monoklonalnym anty-CD20 Ofa. W dwuramiennym randomizowanym badaniu III fazy Study 119 (\#NCT01659021) porównano skuteczność schematu Ofa-idelalizyb $(\mathrm{n}=174)$ do Ofa-placebo $(\mathrm{n}=87)$ [39]. Ofatumumab podawano łącznie w 12 infuzjach. W grupie leczonej według schematu Ofa-idelalizyb dawka początkowa wynosiła $300 \mathrm{mg}$, następnie podawano 7 kursów po $1000 \mathrm{mg}$ cotygodniowo i kolejne 4 kursy w dawce $1000 \mathrm{mg}$ co 4 tygodnie. W grupie $z$ placebo dawki Ofa w podaniach 2.-12. były zwiększone do $2000 \mathrm{mg}$. Idelalizyb podawano w dawce $150 \mathrm{mg} 2 \mathrm{razy} /$ dobę. Badanie to potwierdziło wyższą skuteczność schematu Ofa-idelalizyb w stosunku do grupy kontrolnej pod względem ORR $(75,3 \% v .18,4 \%)$, redukcji limfadenopatii $(93,3 \% v .4,9 \%)$, PFS (mediana 16,3 $v .8,0$ miesięcy). Korzystny efekt utrzymywał się również w grupie pacjentów $\mathrm{z}$ obecnością del 17p13 lub mutacji TP53 (mediana PFS 13,7 v. 5,8 miesiąca). Nie zaobserwowano jednak różnic w OS (mediana 20,9 v. 19,4 miesiąca) [39].

Wysoka skuteczność idelalizybu w połączeniu $z$ przeciwciałami monoklonalnymi anty-CD20 obserwowana u pacjentów $z$ nawrotowymi i opornymi postaciami CLL była powodem rozpoczęcia badań klinicznych u dotychczas nieleczonych chorych [40, 41]. Do badania II fazy (\#NCT01203930) O'Brien i wsp. [40] zakwalifikowali chorych w wieku powy$\dot{z}$ ej 65. roku życia $z$ rozpoznaniem CLL $(n=59)$ oraz chłoniaka $z$ małych limfocytów (SLL, small lymphocytic lymphoma $(\mathrm{n}=5)$. Idelalizyb podawano codziennie w dawce $150 \mathrm{mg} 2 \mathrm{razy} /$ dobę, natomiast $\mathrm{R} \mathrm{w}$ dawce $375 \mathrm{mg} \mathrm{w} 8$ cotygodniowych infuzjach. W badaniu tym wykazano, że kombinacja idelalizybu wraz z R w populacji dotychczas nieleczonych starszych chorych wykazuje wysoką skuteczność kliniczną z ORR na poziomie $97 \%$, przy czym $19 \%$ pacjentów uzyskało $\mathrm{CR}$. Ponadto również w grupie pacjentów $z$ del 17p13 lub mutacją TP53 $(\mathrm{n}=13)$ oraz niezmutowanym $\operatorname{IgVH}(\mathrm{n}=37)$ kombinacja tych leków charakteryzowała się wysokim odsetkiem ORR, odpowiednio: $100 \%$ (33\% CR) oraz $97 \%$ (8\% CR). Niemniej jednak u 19 (29,7\%) chorych przerwano leczenie $z$ powodu działań niepożądanych [40]. Wysoki odsetek działań niepożądanych obserwowano równie $\dot{z} \mathrm{w}$ populacji dotychczas nieleczonych 24 osób (23 pacjentów z CLL oraz 1 chory z SLL) w wieku poniżej 65. roku życia [41]. W badaniu II fazy Lampson i wsp. (\#NCT02135133) [41] pacjenci byli leczeni przez pierwsze 56 dni wyłącznie idelalizybem w dawce $150 \mathrm{mg} 2$ razy/dobę w monoterapii, a następnie do leczenia przez kolejnych 6 miesięcy dołączano Ofa. Lek ten podawano pierwszorazowo $\mathrm{w}$ dawce $300 \mathrm{mg}$, następnie po $1000 \mathrm{mg}$ w odstępach 28-dniowych. Obserwowano wysoki odsetek hepatotoksyczności objawiającej się jako wzrost enzymów wątrobowych u 19 pacjentów $(79 \%)$. Powikłania tego nie stwierdzano $\mathrm{w}$ takim natężeniu we wcześniejszych badaniach.

W związku z tymi niepokojącymi działaniami niepożądanymi, a zwłaszcza ze względu na zwiększony odsetek zgonów w przebiegu powikłań infekcyjnych $\mathrm{w}$ ramionach $\mathrm{z}$ idelalizybem $\mathrm{w}$ toczących się 7 innych badaniach klinicznych II i III fazy, wstrzymano rekrutację dalszych pacjentów do tych badań [41]. Zaskakujące obserwacje na temat wyższej toksyczności leczenia idelalizybem w grupie pacjentów dotychczas nieleczonych, jak również pozostałe charakterystyczne działania niepożądane leku zostały szerzej omówione w kolejnym rozdziale. 


\section{Profil działań niepożądanych idelalizybu}

W przypadku stosowania idelalizybu w opornych i nawrotowych postaciach CLL do najczęstszych raportowanych powikłań I i II stopnia według Common Terminology Criteria for Adverse Events (CTCAE) w badaniach I oraz II fazy należały: zmęczenie, biegunka, mdłości, dreszcze oraz wysypka. Toksyczności III i IV stopnia dotyczyły występowania: biegunki (14\%), wzrostu aktywności transaminaz wątrobowych (14\%) i zapaleń płuc (3\%) (tab. 1), które stanowiły często główną przyczynę odstawienia leku [42]. Powikłania skórne oraz wzrost transaminaz wątrobowych odpowiadały za wczesne zakończenie leczenia idelalizybem w $23 \%$ przypadków [43].

Leczenie idelalizybem, zarówno w monoterapii, jak i w kombinacji $z$ innymi lekami cytostatycznymi, może prowadzić do wzrostu transaminaz, które jest obserwowane przeważnie w ciągu pierwszych 8 tygodni terapii (mediana 5,3 tygodnia) w przypadku chorych z CLL poddanych wcześniej leczeniu cytostatycznemu. Poziom aktywności aminotransferazy alaninowej (ALT, alanine transaminase) i aminotransferazy asparaginianowej (AST, aspartate transaminase) w zdecydowanej większości przypadków normalizuje się po tymczasowym odstawieniu leku lub zmniejszeniu jego dawki po wznowieniu leczenia do $100 \mathrm{mg} 2 \mathrm{razy} /$ dobę, jednak w niektórych przypadkach obserwowano ostrą niewydolność wątroby na tle autoimmunizacyjnego zapalenia [41, 42]. W przypadku kombinacji idelalizybu $z$ Ofa zanotowano 1 zgon $w$ badaniu III fazy $\mathrm{w}$ przebiegu ostrej niewydolności wątroby, jednak równolegle u pacjenta stwierdzono sepsę [42]. Podwyższenie aktywności transaminaz obserwowano w szczególności u młodych chorych z CLL, u których idelalizyb był stosowany $\mathrm{w}$ kombinacji $z$ Ofa jako leczenie pierwszej linii [41]. W tym badaniu wzrost enzymów wątrobowych zanotowano u 19 pacjentów (79\%), co przyczyniło się do konieczności modyfikacji protokołu badania. U młodych pacjentów z CLL włączano prednizon w dawce $1 \mathrm{mg} / \mathrm{kg} \mathrm{mc}$. już w przypadku umiarkowanego wzrostu transaminaz wątrobowych (I stopień toksyczności wg CTCAE), co częściowo zapobiegło rozwojowi ciężkich postaci niewydolności wątroby [41]. W przypadku starszych chorych rekomenduje się włączenie prednizonu przy wzroście aktywności transaminaz odpowiadającemu IV stopniowi według CTCAE [42].

Również charakterystycznym powikłaniem leczenia idelalizybem są biegunka oraz zapalenie jelita, które stwierdza się u około $14 \%$ pacjentów $z$ postaciami opornymi-nawrotowymi CLL oraz aż u $23 \%$ chorych leczonych tym lekiem w pierwszej linii. W około $11 \%$ przypadków powikłania ze strony przewodu pokarmowego były przyczyną przedwczesnego zakończenia leczenia [42, 43]. W przypadku tego inhibitora stwierdza się dwie różne postaci biegunki, obie o charakterze śluzowo-wodnistym. Pierwszy typ biegunek, odpowiadający na leczenie objawowe lekami antymotorycznymi, pojawia się zwykle do 8 tygodni od czasu rozpoczęcia terapii idelalizybem. Natomiast drugi typ biegunki występuje później (po kilku miesiącach od rozpoczęcia leczenia) i nie reaguje na leczenie lekami antymotorycznymi oraz zmianę diety, prawdopodobnie ze względu na często towarzyszący proces zapalny błony śluzowej jelita [44, 45]. Warto nadmienić, że w trakcie leczenia idelalizybem zanotowano 6 śmiertelnych przypadków perforacji jelita grubego. W przypadku 4 chorych perforacje poprzedziły biegunka lub proces zapalny jelita, natomiast w 2 pozostałych przypadkach wspólistniały nowotwory złośliwe przewodu pokarmowego (rak okrężnicy oraz rak trzustki) [42].

Groźnym powikłaniem leczenia idelalizybem jest śródmiąższowe zapalenie płuc (ok. 3\% pacjentów $z$ nawrotową i oporną postacią CLL), które występuje przeważnie po kilkumiesięcznej terapii (mediana 8 miesięcy) i jest często przyczyną jej zakończenia [42, 46]. Uzyskane dotychczas dane kliniczne wskazują, że w około $30 \%$ przypadków idelalizyb prowadzi również do rozwoju neutropenii III i IV stopnia według CTCAE [42, 46]. Ostatnio przeprowadzona częściowa analiza wyników toczących się badań III fazy, które analizowały skuteczność idelalizybu w połączeniu $z \mathrm{~B}$ oraz rytuksymabem w CLL oraz chłoniaku grudkowym, wykazała znacząco wyższy odsetek śmiertelności $\mathrm{u}$ chorych leczonych terapią skojarzoną $\mathrm{z}$ idelalizybem $(7,4 \%)$ w porównaniu $z$ tymi, którzy otrzymywali B w polączeniu $\mathrm{z} \mathrm{R}$ lub w monoterapii $(3,5 \%)$ [46]. W konsekwencji tych niepokojących obserwacji badania $z$ zastosowaniem idelalizybu zostały tymczasowo wstrzymane (oświadczenie Agencji ds. Żywności i Leków [FDA, Food and Drug Administration], marzec 2016 r.). Analiza przyczyn zgonów wykazała istotnie wyższy odsetek zapaleń płuc o etiologii Pneumocystis jiroveci oraz reaktywacji CMV, których nie obserwowano w takim nasileniu $\mathrm{w}$ badaniu fazy Ib $[32,34]$.

Dość dobra tolerancja idelalizybu w monoterapii lub $\mathrm{w}$ połączeniu $\mathrm{z} \mathrm{R}$ była podstawą badania skuteczności tego inhibitora $\mathrm{PI} 3 \mathrm{~K} \delta \mathrm{w}$ kombinacji $z$ innymi środkami cytostatycznymi czy związkami drobnocząsteczkowymi skutecznymi w leczeniu CLL, takimi jak pozostałe inhibitory szlaku BCR. 
Kombinacje idelalizybu $z$ innymi lekami nie przyniosły już tak obiecujących rezultatów w odniesieniu do tolerancji leczenia jak badania I i II fazy u chorych $z$ nawrotowymi i opornymi postaciami CLL [47-49]. Nieoczekiwanie połączenie idelalizybu, lenalidomidu oraz rytuksymabu było źle tolerowane i prowadziło do przedwczesnego zakończenia 2 badań klinicznych wskutek wystąpienia poważnych powikłań zagrażających życiu pacjentów. W badaniu Smith i wsp. [47] łącznie wśród 8 pacjentów obserwowano powikłania III stopnia: podwyższenie aktywności transaminaz wątrobowych, wysypkę, hipotonię, zapalenie pluc oraz syndrom posocznico-podobny. Cheah i wsp. [48] w swoim badaniu wykazali natomiast wzrost transaminaz III stopnia i wyższego u 6 z 7 chorych, w tym 2 zgony (jeden w wyniku ostrej niewydolności wątroby oraz drugi z powodu niewydolności oddechowej w przebiegu bakteriemii Gram-dodatnimi drobnoustrojami). Również połączenie idelalizybu $z$ entospletynibem (inhibitor SYK) doprowadziło do zapalenia płuc u 11 (17\%) pacjentów, przy czym 5 (8\%) wymagało mechanicznego wspomagania wentylacji, a 2 zmarło wskutek postępującej niewydolności oddechowej [49].

Biorąc pod uwage obserwowane powikłania ze strony wątroby, przewodu pokarmowego oraz płuc, dotychczasowe wyniki badań zdają się wskazywać na ich immunologiczne podłoże. Idelalizyb wskutek hamowania aktywności PI3K $\delta$ w prawidłowych limfocytach B oraz komórkach pamięci może prowadzić do wzrostu aktywności limfocytów cytotoksycznych CD8+ oraz spadku tolerancji immunologicznej [46, 50]. Hipotezę tę potwierdzają pośrednio wyniki badań histopatologicznych bioptatów wątroby [41], błony śluzowej jelita grubego $[44,45,51]$ oraz płuc [42], w których wykazano nacieki złożone $z$ komórek $\mathrm{CD} 8+$. W badaniu Lampson i wsp. [41] hepatotoksyczności leku u pacjentów towarzyszyło podwyższenie stężeń cytokin prozapalnych CCL3 oraz CCL4. Ponadto część badanych odpowiada na systemową terapię steroidami, co dodatkowo potwierdza udział limfocytów cytotoksycznych CD8+ w rozwoju tych groźnych powikłań $[42,46]$. Warto zwrócić uwagę, że profil toksyczności idelalizybu różni się w zależności od grupy leczonych pacjentów $z$ CLL. W przypadku chorych, u których stosowano idelalizyb w pierwszej linii leczenia, odsetek powikłań autoimmunologicznych oraz odsetek chorych zaprzestających leczenia (ok. $40 \%$ pacjentów) są znacznie wyższe niż w przypadku pacjentów, u których stosowane było już wcześniej leczenie cytostatyczne (odsetek odstawienia leku $<10 \%)[43,51]$.
Przyczyny odstawienia idelalizybu oraz dalszy przebieg leczenia u 40 pacjentów z CLL, którzy otrzymywali lek w kombinacji $z \mathrm{R}$ w pierwszej linii leczenia, przeanalizowali Thompson i wsp. [51]. W wymienionym badaniu mediana obserwacji wynosiła 36 miesięcy (18-43), przy czym nie osiągnięto mediany PFS oraz OS. W całej badanej grupie ORR wynosił 95\% (14,7\% CR). W czasie analizy wyników spośród 40 przypadków 17 pacjentów kontynuuje leczenie idelalizybem, natomiast terapię zakończono u 23 chorych. Powodem całkowitego zaprzestania leczenia były: działania niepożądane $(\mathrm{n}=15)$, śmierć $\mathrm{w}$ remisji choroby $(\mathrm{n}=4)$, progresja choroby $(\mathrm{n}=2$; po 28,3 oraz 37,5 miesiącach leczenia), pierwotna oporność $(n=1)$ oraz aplazja czysto czerwonokrwinkowa $(\mathrm{n}=1)$. Dziesięciu pacjentów spośród 15, którzy lek odstawili z powodu działań niepożądanych, w okresie obserwacji wykazywało cechy progresji choroby lub otrzymało kolejną linię leczenia. Głównymi przyczynami odstawienia leku $z$ powodu działań niepożądanych były biegunka oraz zapalenia jelita grubego stwierdzane u 7 pacjentów. $Z$ powodu pneumonitis leczenia zaprzestano u 4 pacjentów (w tym 1 zgon), natomiast w pojedynczych przypadkach lek odstawiono $z$ powodu: podwyższonej aktywności enzymów wątrobowych, wysypki, bóli brzucha, zmęczenia oraz nawrotowych infekcji. Mediana czasu do odstawienia leczenia $z$ powodu działań niepożądanych wynosiła 11 miesięcy [51]. Mimo zaprzestania leczenia idelalizybem u 4 pacjentów obserwowano utrzymanie się odpowiedzi klinicznej (mediana obserwacji 23,3 miesiąca; 8,5-28,6 miesiąca), natomiast u 10 stwierdzono progresję choroby, przy czym w 7 przypadkach konieczne było rozpoczęcie kolejnej linii leczenia cytostatycznego. Analiza jednoczynnikowa wykazała, że zmutowany $\operatorname{IgVH}$ oraz brak ekspresji ZAP-70 stanowią czynnik dobrego rokowania i trwałego utrzymania się odpowiedzi klinicznej po zakończeniu leczenia idelalizybem [51].

Reasumując, działania niepożądane idelalizybu obserwowane $u$ pacjentów $z$ CLL mogą wynikać $z$ upośledzenia odporności w stosunku do samych patogenów, jak również $z$ upośledzonej tolerancji immunologicznej. Ponadto mimo przerwania leczenia idelalizybem u części pacjentów utrzymuje się długotrwała odpowiedź kliniczna.

\section{Zarządzanie działaniami niepożądanymi w trakcie leczenia idelalizybem}

Charakterystyczne działania niepożądane idelalizybu wraz $z$ proponowanym algorytmem 
prewencji oraz postępowania w przypadku ich wystąpienia przedstawiono $\mathrm{w}$ tabeli 2 . Wszelkie ciężkie reakcje alergiczne oraz anafilaktyczne są bezwzględnym przeciwwskazaniem do leczenia idelalizybem. W przypadku biegunek pierwszego typu rekomenduje się zmianę nawyków dietetycznych, przyjmowanie płynów obojętnych oraz stosowanie leków antymotorycznych (np. loperamid). W przypadku nawrotowych i ciężkich postaci biegunek oraz biegunek typu drugiego związanych $z$ procesem zapalnym błony śluzowej jelita (III i IV stopnia według CTCAE) skuteczność wykazało odstawienie idelalizybu do czasu ustąpienia dolegliwości, a następnie włączenie leku w zredukowanej dawce $100 \mathrm{mg} 2 \mathrm{razy} /$ dobę. W przypadku braku skuteczności takiego postępowania należy rozważyć doustne leczenie budezonidem lub systemową steroidoterapię prednizonem w dawce $1 \mathrm{mg} / \mathrm{kg} \mathrm{mc}$. Średnia czasu do ustąpienia biegunki w przypadku zastosowania leczenia wynosi 12,1 dnia (zakres 1-35 dni). Taka strategia postępowania przynosi trwałą korzyść u około $60 \%$ pacjentów [42]. Niemniej jednak w przypadku obecności krwi w stolcu zalecane jest wdrożenie diagnostyki endoskopowej przed podjęciem leczenia steroidami.

Wzrost enzymów wątrobowych obserwowany $\mathrm{w}$ trakcie leczenia idelalizybem w I i II stopniu według CTCAE nie wymaga wstrzymania leczenia, jednak poziom aktywności ALT i AST należy monitorować przynajmniej raz w tygodniu do czasu spadku aktywności do poziomu nie większego niż $1 \times$ górna granica normy. $\mathrm{W}$ przypadku powikłania III i IV stopnia według CTCAE należy wstrzymać leczenie do czasu spadku aktywności ALT i AST do I stopnia według CTCAE, a następnie ponownie włączyć idelalizyb w dawce zredukowanej do $100 \mathrm{mg} 2$ razy/dobę. Jeśli zdarzenie niepożądane nie powtórzy się, należy rozważyć powrót do dawki $150 \mathrm{mg} 2 \mathrm{razy} /$ dobę. W przypadku ponownego wystąpienia zdarzenia po redukcji dawki leku zalecane jest odstawienie idelalizybu i jego ponowne włączenie w dawce $100 \mathrm{mg} 2$ razy/dobę po normalizacji aktywności ALT i AST lub spadku ich stężeń do I stopnia według CTCAE. W przypadku pogorszenia parametrów wydolności wątroby rozważyć włączenie prednizonu $1 \mathrm{mg} / \mathrm{kg} \mathrm{mc}$. [42, 46].

W przypadku podejrzenia zapalenia płuc rekomendowane jest wstrzymanie leczenia idelalizybem oraz wdrożenie postępowania diagnostycznego w celu wyjaśnienia etiologii zgłaszanych przez pacjenta dolegliwości. Oprócz badania rentgenowskiego klatki piersiowej, zalecane jest również wykonanie tomografii komputerowej wysokiej rozdzielczości (HRCT, high-resolution computed tomography), aby wykluczyć śródmiąższowe zapalenie płuc, oraz badań mikrobiologicznych (do rozważenia wykonanie bronchoskopii $z$ pobraniem popłuczyn oskrzelikowo-pęcherzykowych [BAL, bronchioalveolar lavage] na badania mikrobiologiczne oraz w kierunku $P$. jirovecii lub infekcji grzybiczej). W przypadku braku identyfikacji czynnika etiologicznego oraz braku poprawy po leczeniu lekami przeciwdrobnoustrojowymi należy rozważyć empiryczne leczenie prednizonem w dawce $1 \mathrm{~g} /$ $/ \mathrm{kg}$ mc. Po ustąpieniu objawów zalecane jest wznowienie leczenia w dawce $100 \mathrm{mg} 2 \mathrm{razy} /$ dobę $[42,46]$.

Ze względu na ryzyko ciężkich infekcji oportunistycznych o etiologii P. jirovecii chorzy leczeni idelalizybem powinni otrzymywać w dawkach profilaktycznych trimetoprim-sulfametoksazol. Skuteczność takiego postępowania profilaktycznego nie została dotychczas wykazana prospektywnie, niemniej żaden $z$ pacjentów otrzymujących trimetoprim-sulfametoksazol nie rozwinął infekcji P. jiroveci [46]. Ponadto przed rozpoczęciem leczenia należy wykonać badania w kierunku zakażenia CMV (stężenie DNA CMV, profil przeciwciał w klasie immunoglobuliny M [IgM] oraz IgG), jak również monitorować wiremię CMV co miesiąc w trakcie terapii [46]. W przypadku biorców CMV-negatywnych rekomendowane jest przetaczanie produktów krwiopochodnych od dawców CMV-negatywnych. Bezobjawowe narastanie wiremii CMV nie jest aktualnie bezwzględnym wskazaniem do rozpoczęcia leczenia gancyklowirem lub walgancyklowirem, jednak należy rozważyć takie postępowanie $\mathrm{w}$ zależności od sytuacji klinicznej [46]. Neutropenia poniżej 0,5 G/1 jest aktualnie wskazaniem do wstrzymania leczenia idelalizybem oraz monitorowania parametrów morfologii raz $\mathrm{w}$ tygodniu. $\mathrm{W}$ przypadku wzrostu stężenia neutrofilii powyżej $0,5 \mathrm{G} / 1$ rekomendowane jest ponowne włączenie idelalizybu w dawce $100 \mathrm{mg}$ 2 razy/dobę [42, 46].

\section{Aktualne miejsce idelalizybu w terapii CLL}

Wysoka skuteczność kliniczna inhibitorów BCR w CLL obserwowana w licznych badaniach klinicznych, w tym szczególnie obiecujące wyniki uzyskane w niekorzystnej rokowniczo grupie pacjentów $z$ defektem szlaku zależnym od genu TP53, są przyczyną szybkiej ewolucji zaleceń terapeutycznych [52, 53]. Zgodnie ze wskazaniami rejestracyjnymi w Europie idelalizyb $\mathrm{w}$ połączeniu $z$ rytuksymabem można zastosować jako leczenie pierwszej linii w przypadku stwierdzonej delecji 17p13 lub mutacji TP53 


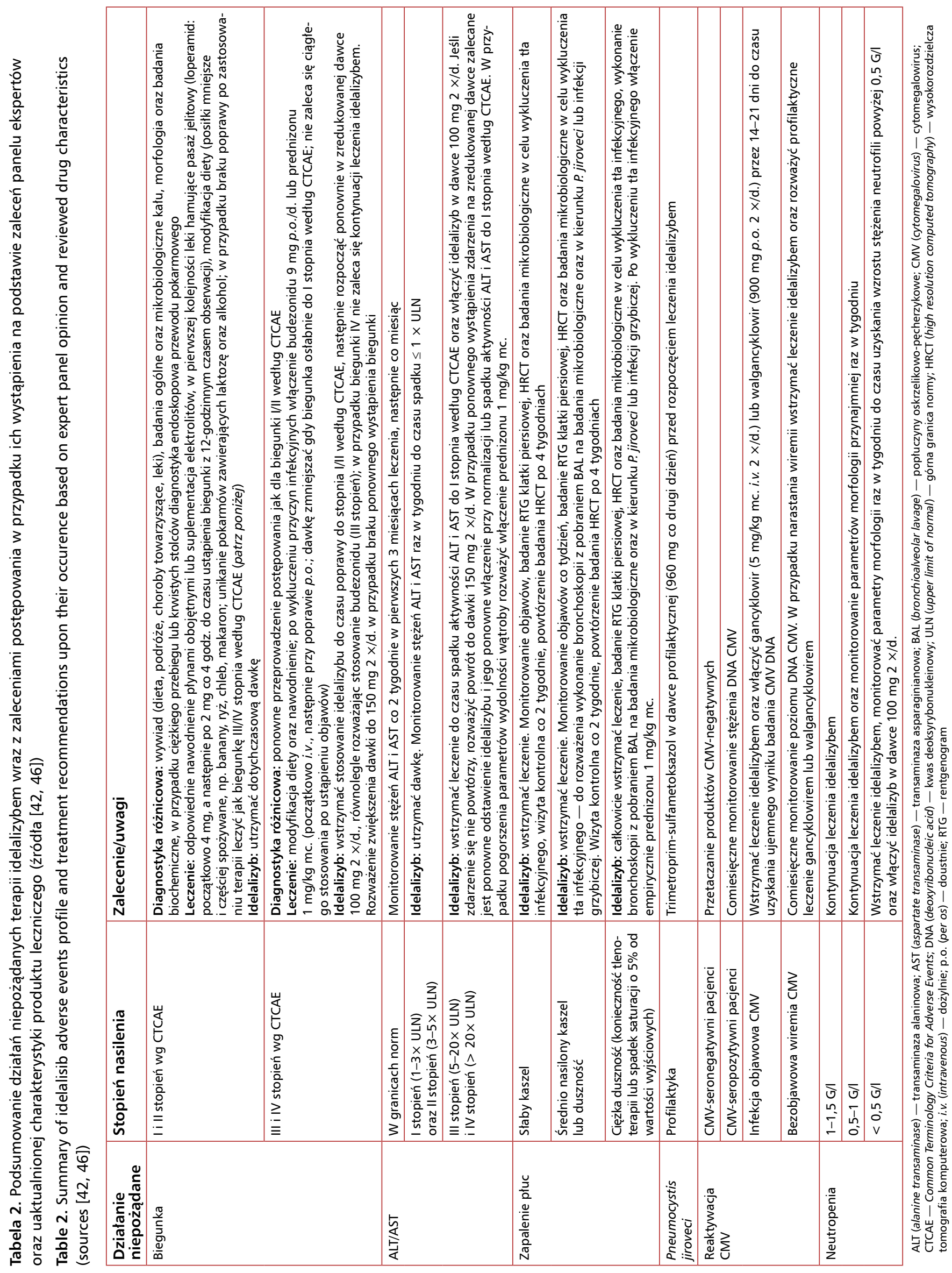




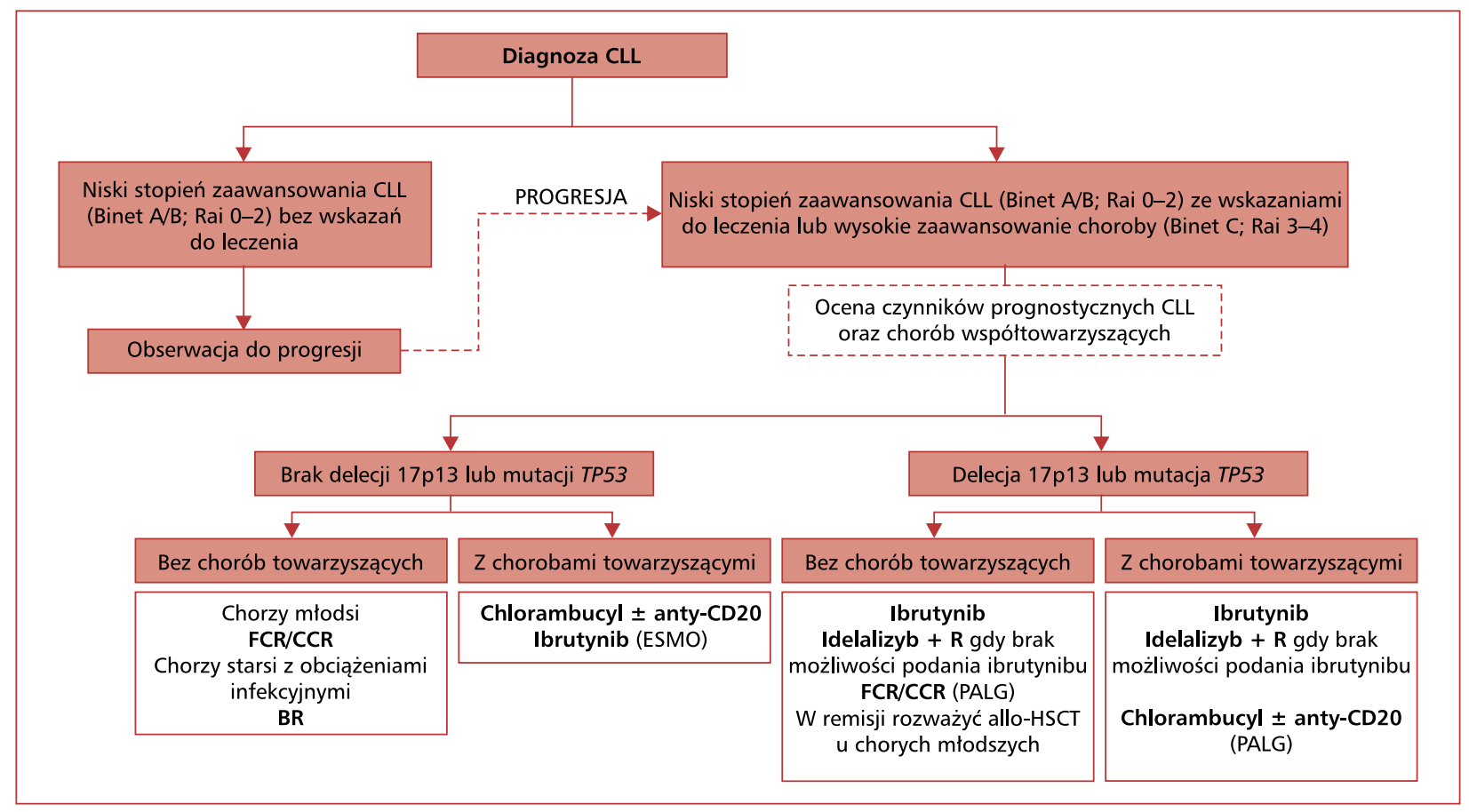

Rycina 1. Algorytm pierwszoliniowego leczenia chorych na przewlekłą białaczkę limfocytową (CLL, chronic lymphocytic leukemia) na podstawie wytycznych European Society for Medical Oncology (ESMO) oraz Stowarzyszenia Polskiej Grupy ds. Leczenia Białaczek (PALG, Polish Adult Leukemia Group); BR — bendamustyna, rytuksymab; FCR — fludarabina, cyklofosfamid, rytuksymab; CCR - kladrybina, cyklofosfamid, rytuksymab; allo-HSCT — allogeniczne przeszczepienie krwiotwórczych komórek macierzystych

Figure 1. Frontline treatment algorithm of patients with chronic lymphocytic leukemia according to European Society for Medical Oncology (ESMO) and Polish Adult Leukemia Group (PALG); BR — bendamustine, rituximab; FCR — fludarabine, cyclophosphamide, rituximab; CCR — cladribine, cyclophosphamide, rituximab; allo-HSCT — allogeneic hematopoietic stem cell transplantation

u pacjentów niekwalifikujących się do chemioimmunoterapii oraz u chorych, którzy otrzymali co najmniej jedną linię leczenia. Zgodnie $z$ wytycznymi European Society for Medical Oncology (ESMO) idelalizyb w połączeniu $z$ rytuksymabem powinien być stosowany u pacjentów w pierwszej linii leczenia $z$ obecnością delecji 17p13 lub mutacji TP53 w przypadku braku możliwości zastosowania ibrutynibu lub obecności przeciwwskazań do jego podania [52]. Idelalizyb nie jest dotychczas w Polsce objęty refundacją, jednak zalecenia Stowarzyszenia Polskiej Grupy ds. Leczenia Białaczek (PALG, Polish Adult Leukemia Group) uwzględniają, analogicznie do zaleceń ESMO, kombinację idelalizybu $z$ rytuksymabem jako leczenie pierwszej linii u pacjentów $\mathrm{z}$ obecnością delecji 17p13 lub mutacji TP53 (ryc. 1) [53]. W obu zaleceniach kombinacja idelalizybu $z$ rytuksymabem stanowi potencjalną opcję terapeutyczną jako kolejna linia leczenia, w szczególności w przypadkach $z$ defektem szlaku zależnego od genu TP53 [52, 53]. Ze względu na liczne powikłania infekcyjne obserwowane w trakcie terapii idelalizybem zarówno ESMO, jak i PALG zalecają prowadzenie leczenia $z$ uwzględnieniem profilaktyki zakażeń $P$. jirovecii oraz monitorowania wiremii CMV $[52,53]$.

\section{Podsumowanie}

Idelalizyb stanowi nową skuteczną opcję terapeutyczną u pacjentów $z$ nawrotową i oporną postacią CLL, w szczególności u chorych $z$ obecnością delecji 17p13 lub mutacji TP53. W grupie chorych $z$ nawrotem lub opornością CLL idelalizyb w połączeniu $\mathrm{z}$ rytuksymabem wykazują wysoką skuteczność kliniczną przy akceptowalnym profilu działań niepożądanych. Zastosowanie leku w pierwszej linii leczenia jest związane $z$ wyższym ryzykiem działań niepożądanych, które mogą prowadzić do konieczności przedwczesnego zakończenia terapii. 


\section{Piśmiennictwo}

1. Eichhorst B., Robak T., Montserrat E. i wsp. Chronic lymphocytic leukaemia: ESMO Clinical Practice Guidelines for diagnosis, treatment and follow-up. Ann. Oncol. 2015; 26 (supl. 5): v78-v84.

2. Hallek M. Prognostic factors in chronic lymphocytic leukemia. Ann. Oncol. 2008; 19 (supl. 4): iv51-iv53.

3. Cramer P., Langerbeins P., Eichhorst B., Hallek M. Advances in first-line treatment of chronic lymphocytic leukemia: current recommendations on management and first-line treatment by the German CLL Study Group (GCLLSG). Eur. J. Haematol. 2016; 96: 9-18.

4. Hallek M. Chronic lymphocytic leukemia: 2015 Update on diagnosis, risk stratification, and treatment. Am. J. Hematol. 2015; 90: 446-460.

5. Rai K.R., Jain P. Chronic lymphocytic leukemia (CLL) — then and now. Am. J. Hematol. 2016; 91: 330-340.

6. Stilgenbauer S., Furman R.R., Zent C.S. Management of chronic lymphocytic leukemia. Am. Soc. Clin. Oncol. Educ. Book 2015: 164-175.

7. Brown J.R., Porter D.L., O'Brien S.M. Novel treatments for chronic lymphocytic leukemia and moving forward. Am. Soc. Clin. Oncol. Educ. Book 2014: e317-e325.

8. Woyach J.A., Johnson A.J., Byrd J.C. The B-cell receptor signaling pathway as a therapeutic target in CLL. Blood 2012; 120: 1175-1184.

9. Burger J.A. Inhibiting B-cell receptor signaling pathways in chronic lymphocytic leukemia. Curr. Hematol. Malig. Rep. 2012; 7: 26-33.

10. Vanhaesebroeck B., Stephens L., Hawkins P. PI3K signalling: the path to discovery and understanding. Nat. Rev. Mol. Cell. Biol. 2012; 13: 195-203.

11. Okkenhaug K., Burger J.A. PI3K Signaling in Normal B Cells and Chronic Lymphocytic Leukemia (CLL). Curr. Top Microbiol. Immunol. 2016; 393: 123-142.

12. Burger J.A., Okkenhaug K. Haematological cancer: idelalisib-targeting PI3Kdelta in patients with B-cell malignancies. Nat. Rev. Clin. Oncol. 2014; 11: 184-186.

13. Ramadani F., Bolland D.J., Garcon F. i wsp. The PI3K isoforms p110alpha and p110delta are essential for pre-B cell receptor signaling and B cell development. Sci. Signal 2010; 3: ra60.

14. Okkenhaug K., Bilancio A., Farjot G. i wsp. Impaired B and T cell antigen receptor signaling in p110delta PI 3-kinase mutant mice. Science 2002; 297: 1031-1034.

15. Jou S.T., Carpino N., Takahashi Y. i wsp. Essential, nonredundant role for the phosphoinositide 3-kinase p110delta in signaling by the B-cell receptor complex. Mol. Cell. Biol. 2002; 22: 8580-8591.

16. Vanhaesebroeck B., Ali K., Bilancio A. i wsp. Signalling by PI3K isoforms: insights from gene-targeted mice. Trends Biochem. Sci. 2005; 30: 194-204.

17. Vanhaesebroeck B., Khwaja A. PI3Kdelta inhibition hits a sensitive spot in B cell malignancies. Cancer Cell. 2014; 25: 269-271.

18. Hoellenriegel J., Meadows S.A., Sivina M. i wsp. The phosphoinositide 3'-kinase delta inhibitor, CAL-101, inhibits B-cell receptor signaling and chemokine networks in chronic lymphocytic leukemia. Blood 2011; 118: 3603-3612.

19. Fiorcari S., Brown W.S., McIntyre B.W. i wsp. The PI3-kinase delta inhibitor idelalisib (GS-1101) targets integrin-mediated adhesion of chronic lymphocytic leukemia (CLL) cell to endothelial and marrow stromal cells. PLoS One 2013; 8: e83830.
20. Miletic A.V., Anzelon-Mills A.N., Mills D.M. i wsp. Coordinate suppression of B cell lymphoma by PTEN and SHIP phosphatases. J. Exp. Med. 2010; 207: 2407-2420.

21. Kang S., Denley A., Vanhaesebroeck B., Vogt P.K. Oncogenic transformation induced by the p110beta, -gamma, and -delta isoforms of class I phosphoinositide 3-kinase. Proc. Natl. Acad. Sci. USA 2006; 103: 1289-1294.

22. Meadows S.A., Vega F., Kashishian A. i wsp. PI3Kdelta inhibitor, GS-1101 (CAL-101), attenuates pathway signaling, induces apoptosis, and overcomes signals from the microenvironment in cellular models of Hodgkin lymphoma. Blood 2012; 119: 1897-1900.

23. Go H., Jang J.Y., Kim P.J. i wsp. MicroRNA-21 plays an oncogenic role by targeting FOXO1 and activating the PI3K/AKT pathway in diffuse large B-cell lymphoma. Oncotarget 2015; 6: 15035-15049.

24. Psyrri A., Papageorgiou S., Liakata E. i wsp. Phosphatidylinositol 3'-kinase catalytic subunit alpha gene amplification contributes to the pathogenesis of mantle cell lymphoma. Clin. Cancer Res. 2009; 15: 5724-5732.

25. Herman S.E., Gordon A.L., Wagner A.J. i wsp. Phosphatidylinositol 3-kinase-delta inhibitor CAL-101 shows promising preclinical activity in chronic lymphocytic leukemia by antagonizing intrinsic and extrinsic cellular survival signals. Blood 2010; 116: 2078-2088.

26. Lannutti B.J., Meadows S.A., Herman S.E. i wsp. CAL-101, a p110delta selective phosphatidylinositol-3-kinase inhibitor for the treatment of B-cell malignancies, inhibits PI3K signaling and cellular viability. Blood 2011; 117: 591-594.

27. Herter S., Palazzo A., Bacac M. i wsp. The PI3K Delta selective inhibitor idelalisib minimally interferes with immune effector function and B cell depletion mediated by obinutuzumab (GA101) and rituximab. Blood 2014; 124: 3342-3342.

28. Davids M.S., Deng J., Wiestner A. i wsp. Decreased mitochondrial apoptotic priming underlies stroma-mediated treatment resistance in chronic lymphocytic leukemia. Blood 2012; 120: 3501-3509.

29. Maffei R., Bulgarelli J., Fiorcari S. i wsp. Endothelin-1 promotes survival and chemoresistance in chronic lymphocytic leukemia B cells through ETA receptor. PLoS One 2014; 9: e98818.

30. Brown J.R., Byrd J.C., Coutre S.E. i wsp. Idelalisib, an inhibitor of phosphatidylinositol 3-kinase p110delta, for relapsed/refractory chronic lymphocytic leukemia. Blood 2014; 123: 3390-3397.

31. Webb H.K., Chen H., Yu A.S. i wsp. Clinical pharmacokinetics of CAL-101, a p110 $\delta$ isoform-selective PI3K Inhibitor, following single- and multiple-dose administration in healthy volunteers and patients with hematological malignancies. Blood 2010; 116: 1774-1774.

32. Barrientos J.C., Coutre S., De Vos S. i wsp. Long-term follow-up of a phase Ib trial of idelalisib (IDELA) in combination with chemoimmunotherapy (CIT) in patients (pts) with relapsed/refractory (R/R) CLL including pts with del17p/TP53 mutation. J. Clin. Oncol. 2015; 33 (supl.): abstr. 7011.

33. Nair K.S., Cheson B. The role of idelalisib in the treatment of relapsed and refractory chronic lymphocytic leukemia. Ther. Adv. Hematol. 2016; 7: 69-84.

34. De Vos S., Furman R.R., Barrientos J.C. i wsp. Idelalisib, a Selective inhibitor of $\mathrm{PI} 3 \mathrm{~K} \delta$, in combination with bendamustine, fludarabine or chlorambucil in patients with relapsed or refractory (R/R) chronic lymphocytic leukemia (CLL). Blood 2013; 122: 2878-2878.

35. Barrientos J.C., Wagner-Johnston N.D., De Vos S. i wsp. Chemoimmunotherapy combination of idelalisib with bendamustine/ 
/rituximab or chlorambucil/rituximab in patients with relapsed/refractory CLL demonstrates efficacy and tolerability. Blood 2013; 122: 4176-4176.

36. Furman R.R., de Vos S., Barrientos J.C. i wsp. Long-term follow-up of a phase 1 Study of Idelalisib (ZYDELIG $\left.{ }^{\circledR}\right)$ in combination with anti-CD20 antibodies (rituximab [R] or ofatumumab [O]) in patients with relapsed or refractory chronic lymphocytic leukemia (CLL). Blood 2014; 124: 5653-5653.

37. Coutre S.E., Leonard J.P., Furman R.R. i wsp. Combinations of the selective phosphatidylinositol 3-kinase-delta (PI3Kdelta) inhibitor GS-1101 (CAL-101) with rituximab and/or bendamustine are tolerable and highly active in patients with relapsed or refractory chronic lymphocytic leukemia (CLL): results from a phase I study. Blood 2012; 120: 191-191.

38. Furman R.R., Sharman J.P., Coutre S.E. i wsp. Idelalisib and rituximab in relapsed chronic lymphocytic leukemia. N. Engl. J. Med. 2014; 370: 997-1007.

39. Jones J.A., Wach M., Robak T. i wsp. Results of a phase III randomized, controlled study evaluating the efficacy and safety of idelalisib (IDELA) in combination with ofatumumab (OFA) for previously treated chronic lymphocytic leukemia (CLL). J. Clin. Oncol. 2015; 33: 7023.

40. O'Brien S.M., Lamanna N., Kipps T.J. i wsp. A phase 2 study of idelalisib plus rituximab in treatment-naive older patients with chronic lymphocytic leukemia. Blood 2015; 126: 2686-2694.

41. Lampson B.L., Kasar S.N., Matos T.R. i wsp. Idelalisib given front-line for treatment of chronic lymphocytic leukemia causes frequent immune-mediated hepatotoxicity. Blood 2016; 128: 195-203.

42. Coutre S.E., Barrientos J.C., Brown J.R. i wsp. Management of adverse events associated with idelalisib treatment: expert panel opinion. Leuk. Lymphoma 2015; 56: 2779-2786.

43. Brown J.R. The PI3K pathway: clinical inhibition in chronic lymphocytic leukemia. Semin. Oncol. 2016; 43: 260-264.
44. Weidner A.S., Panarelli N.C., Geyer J.T. i wsp. Idelalisib-associated Colitis: histologic findings in 14 patients. Am. J. Surg. Pathol. 2015; 39: 1661-1667.

45. Louie C.Y., DiMaio M.A., Matsukuma K.E. i wsp. Idelalisib-associated enterocolitis: clinicopathologic features and distinction from other enterocolitides. Am. J. Surg. Pathol. 2015; 39: 1653-1660

46. Cheah C.Y., Fowler N.H. Idelalisib in the management of lymphoma. Blood 2016; 128: 331-336.

47. Smith S.M., Pitcher B., Jung S.-H. i wsp. Unexpected and serious toxicity observed with combined idelalisib, lenalidomide and rituximab in relapsed/refractory B cell lymphomas: alliance A051201 and A051202. Blood 2014; 124: 3091-3091.

48. Cheah C.Y., Nastoupil L.J., Neelapu S.S. i wsp. Lenalidomide, idelalisib, and rituximab are unacceptably toxic in patients with relapsed/refractory indolent lymphoma. Blood 2015; 125: 3357-3359.

49. Barr P.M., Saylors G.B., Spurgeon S.E. i wsp. Phase 2 study of idelalisib and entospletinib: pneumonitis limits combination therapy in relapsed refractory CLL and NHL. Blood 2016; 127: 2411-2415.

50. Cheah C.Y., Fowler N.H., Wang M.L. Breakthrough therapies in B-cell non-Hodgkin lymphoma. Ann. Oncol. 2016; 27: 778-787.

51. Thompson P.A., Stingo F., Keating M.J. i wsp. Outcomes of patients with chronic lymphocytic leukemia treated with first-line idelalisib plus rituximab after cessation of treatment for toxicity. Cancer 2016; 122: 2505-2511.

52. Eichhorst B., Robak T., Montserrat E. i wsp. Appendix 6: Chronic lymphocytic leukaemia: eUpdate published online September 2016 (http://www.esmo.org/Guidelines/Haematological-Malignancies). Ann. Oncol. 2016; 27 (supl. 5): v143-v144.

53. Robak T., Hus I., Giannopoulos K. i wsp. Rekomendacje diagnostyczne i terapeutyczne dla przewlekłej białaczki limfocytowej w 2016 r. - Raport Grupy Roboczej PTHiT i PALG-CLL. Acta Hematol. Pol. 2016; 47: 169-183. 